\title{
The effects of tibiofibularis anterior ligaments on ankle joint biomechanics
}

\author{
Ahmet Karakaşlı, M.D., ${ }^{1}$ Mehmet Erduran, M.D., ${ }^{1}$ Lütfü Baktıroğlu, M.D., ${ }^{2}$ \\ Aydın Büdeyri, M.D., ${ }^{3}$ Didem Venüs Yıldız, M.D., ${ }^{4}$ Hasan Havıtçıoğlu, M.D. ${ }^{1}$ \\ ${ }^{1}$ Department of Orthopedics and Traumatology, Dokuz Eylul University Faculty of Medicine, Izmir; \\ 2Department of Orthopedics and Traumatology, Canakkale Onsekiz Mart University Faculty of Medicine, Canakkale \\ ${ }^{3}$ Department of Orthopedics and Traumatology, Private Sani Konukoglu Hospital, Gaziantep; \\ ${ }^{4}$ Department of Biomechanics, Institute of Health Science, University of Dokuz Eylul, Izmir
}

\begin{abstract}
BACKGROUND: The aim of this study was to evaluate the biomechanical behavior of anterior inferior tibiofibularis ligament (AITFL) deficient human ankle under axial loading of ankle at stance phase of gait. In order to investigate the contribution of AITFL to ankle stability, an in vitro sequential experimental setup was simulated.
\end{abstract}

METHODS: The measurement of posterior displacement of distal tibia and anterior displacement of the foot, in neutral position, secondary to axial compression, was performed by two non-contact video extensometers. Eight freshly frozen, anatomically intact, cadaveric human ankle specimens were included and tested. An axial compression test machine was utilized from 0 to $800 \mathrm{Newton}$ swith a loading speed of $5 \mathrm{~mm} / \mathrm{min}$ in order to simulate the axial weight-bearing sequence of the ankle at stance phase of human gait.

RESULTS: There was a statistically significant difference between anteroposterior displacement values for AITFL-Intact and AITFLDissected specimens $(p \leq 0.05)$. Mean AITFL-Intact and mean AITFL-Dissected ankle anteroposterior displacement was $1.28 \pm 0.47 \mathrm{~mm}$ and $2.06 \pm 0.7 \mathrm{~mm}$, respectively.

CONCLUSION: This study determined some numerical and quantitative data about the biomechanical properties of AITFL in neutral foot position. In the emergency department, diagnosis and treatment of AITFL injury, due to ankle distortion, is important. In AITFL injuries, ankle biomechanics is affected, and ankle instability occurs.

Key words: Ankle biomechanics; anterior inferior tibiofibular ligament; axial compression test; displacement; non-contact measurement.

\section{INTRODUCTION}

Ankle injuries are common in all levels of daily activities and sport traumas, varying in severity, degree and location. Most commonly, ankle injuries are located at the lateral ankle region, especially on anterior talofibular ligaments and anterior inferior tibiofibular ligaments (AITFL).

Three quarters of ankle injuries involve the lateral ligamen-

Address for correspondence: Ahmet Karakaşlı, M.D.

Dokuz Eylül Üniversitesi Tıp Fakültesi, Ortopedi ve Travmatoloji

Anabilim Dalı, İnciraltı, İzmir, Turkey

Tel: +90 232 - 4123353 E-mail: akarakasli@mailcity.com

Qucik Response Code Ulus Travma Acil Cerrahi Derg

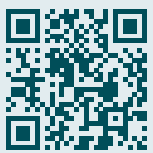

20I5;2I(2):90-95

doi: $10.5505 /$ tjtes.2015.27I63

Copyright 2015

TJTES tous complex. ${ }^{[1,2]}$ Compared with the lateral ankle sprain, syndesmosis sprains are uncommon and noted less frequently. The incidence of syndesmosis injuries is reported $1 \%$ to $11 \%$ of all ankle injuries. ${ }^{[3-5]}$ Although much research has focused on injury to lateral ankle ligaments and inversion ankle sprain, studies in the literature regarding the injury of the anterior inferior tibiofibular ligament are limited. ${ }^{[3]}$

Syndesmotic injuries are still often undetected and diagnosed only after a simple ankle sprain fails to heal. ${ }^{[2]}$ Syndesmosis injuries are a greater source of impairment than the typical lateral ankle sprain. ${ }^{[4]}$ Partial disruption of syndesmosis is difficult to diagnose. ${ }^{[6]}$ The leading cause of AITFL impingement lesions is posttraumatic ankle injuries, usually ankle sprains, resulting in chronic ankle pain. ${ }^{[7]}$

Taking foot biomechanics into consideration is essential for clinicians during the treatment of ankle instability, which is especially the case for any surgical repair of injured ankle ligaments. ${ }^{[8]}$ Biomechanical functions of the ligaments are to 
resist external load, guide relative movements of the two bones, and control the maximum range of joint motion. In determining the mechanical properties of the ligaments, tissue condition and test methods are particularly important (e.g. temperature, moisture content, strain rate, and previous loading history influence the tensile properties).

Biomechanical research on distal tibiofibular syndesmosis injury mechanisms is also rare. ${ }^{[9]}$ This kind of injury is difficult to evaluate and diagnose, ${ }^{[10]}$ and has a longer recovery time than other ankle sprains. ${ }^{[9,11]}$

A common ankle trauma mechanism usually initiates with an acute and inadequate axial loading trauma on the ankle, and then the load distribution on the ankle diverges to the medial and lateral ankle ligaments triggering the injury mechanism to the ankle syndesmosis. However, more often, while the lateral ankle region is the most commonly injured side, the medial is the least injured since the medial ligamentous complex is stronger and more resistant than the lateral complex..$^{[3,12]}$ This anatomic differentiation results in a relatively unbalanced moment distribution on the lateral and medial constraints. Center point of moment on ankle changes position towards the medial side of ankle and far to the lateral. This type of acute relative load distribution results in an increased energy concentration on the lateral side and higher incidence of lateral ankle injuries. ${ }^{[3]}$

Distal fibula is firmly attached at the tibial notch of the tibia by several syndesmotic ligaments. ${ }^{[3,5]}$ There are three main ligaments that add stability to distal tibiofibular syndesmosis including the anterior inferior tibiofibular ligament (AITFL), the posterior tibiofibular ligament (PITFL), and the interosseous ligament. ${ }^{[1-4]}$ Anterior inferior tibia fibular ligament is a flat strong ligament that originates from the longitudinal tubercle on the anterior aspect of the lateral malleolus and fibers course superiorly and medially attaching on the anterolateral tubercle of tibia. This ligament, in addition to holding the fibula tight to the tibia, prevents excessive fibular movement and external talar rotation. ${ }^{[3,4]}$ AITF ligament is the most frequently injured ligament in syndesmosis rupture of the AITF ligament that can lead to separation between the tibia and fibula. Most commonly, the AITFL is ruptured. ${ }^{[2,13]}$

This anterior syndesmotic diastasis is an open book injury resulting from external rotation of the fibula. Tibia fibular ligament sprains are important since they have a longer recovery time, and they may develop subsequent chronic ankle instability.

In most previous studies, syndesmosis and anterior inferior tibiofibular ligament biomechanical investigations were carried out under axial load. ${ }^{[5,14]}$

In this study, talus anterior displacement was measured under axial load in two situations of intact anterior inferior tibio- fibular ligament and sectioned anterior inferior tibiofibular ligament. The aim of the present study was to examine the mechanical behavior of human ankle AITFL at same force (800 Newtons) and investigate the instability of talus biomechanically.

In this study our aim was to investigate the talar instability in AITFL rupture. To measure the displacement and instability of ankle joint, talus was chosen to be a landmark as the major mechanical and anatomic constraint of the ankle joint.

\section{MATERIALS AND METHODS}

In order to investigate the contribution of anterior inferior tibiofibularis ligament to ankle stability under axial compression force, in vitro measuring of the anterior foot displacement was sequentially simulated under experimental biomechanical setup. According to the procedure of this study, eight freshly frozen, cadaveric human ankle specimens, amputated I inch below the tibial tuberosity level, examined to have no incompatibility in any aspects of anatomical structures were included into the study. The specimens included were positioned neutrally in the experimental setup of axial compression test machine (AG-IS 10 kN, Shimadzu Corporation, Kyoto, Japan) in order to simulate axial weight-bearing of ankle at the stance phase of human gait. Moreover, two conditions for the human anterior inferior tibiofibular ligament (AITFL) were simulated, AITFL-Intact and AITFL-Dissected, to evaluate its contribution to anterior stability of ankle at this phase of human gait. Afterwards, distal tibia was marked $\mathrm{I} \mathrm{cm}$ above ankle joint level and also neck of talus bone with pinned gauge marks of non-contact video extensometer (Non-contact Video Extensometer DVE-10I/20I, Shimadzu Corporation, Kyoto, Japan). Talus was chosen a landmark, which is the main anatomical and biomechanical constraint of the ankle joint. Subsequently, axial compression load of maximum 800 Newtons was applied gradually from 0 to 800 Newtons with a loading speed of $5 \mathrm{~mm} / \mathrm{min}$. Simultaneously, the resulting displacements of the gauge marks during the anterior spin of the foot and the posterior spin of the distal tibia were captured by perpendicularly lateral positioned noncontact CCD cameras and were measured via non-contact video extensometer (Non-contact Video Extensometer DVE-I0I/20I, Shimadzu Corporation, Kyoto, Japan). The inbuilt double camera which has an absolute accuracy depending on the smaller field of view, is able to measure the minor displacements with a low standard error. In our study absolute error is $+/-3 \times 10^{-3} \mathrm{~mm}$ and the relative error is $+/-1 \%$ of the elongation (room temperature).

\section{Specimens}

Eight freshly frozen, cadaveric human ankle specimens, amputated I inch below the tibial tuberosity level, examined to have no incompatibility in any aspects of the anatomical structures were included into the study. The specimens included were positioned neutrally in the experimental setup 
of axial compression test machine (AG-IS $10 \mathrm{kN}$, Shimadzu Corporation, Kyoto, Japan) in order to simulate axial weightbearing of ankle at stance phase of human gait. Researchers were blind to all human subjects of the specimens. Seven of the specimens were from men and one was from a woman. Median age of the patients to whom the specimens belonged was 66 years (range, 54-80) at the time of operation. There were no ligamentous pathology, joint pathology, and osteoarthritis in the ankles of the patients. The specimens were noted to have intact ligaments by direct visualization after dissection. After the tests were performed for intact ligaments of human ankles, anterior tibiofibular ligament of each specimen was dissected.

\section{Test Machine}

The test machine (AG-IS 10 kN, Shimadzu Corporation, Kyoto, Japan) which was set up in our biomechanics laboratory could apply axial compression to the ankle with foot. The test machine consisted of load cell $(\max .5 \mathrm{kN})$ attached to the crosshead of the main body, compression plates (upper plate and lower plate), adapter for compression including screw, table (support) of bending and controller. The test device had data processing software (TRAPEZIUM2, Shimadzu Corporation, Kyoto, Japan) and non-contact video extensometer (DVE-I0I/20I, Shimadzu Corporation, Kyoto, Japan) which was an elongation meter that enabled elongation measurement without making contact with the test specimen. Figure I illustrates the test arrangement.

\section{Methods}

This laboratory based study was carried out in the Biomechanical Laboratory of Institute of Health Sciences of Faculty of Medicine of Dokuz Eylul University. In this study, axial loads were applied vertically to eight specimens during foot at neutral position. The study was conducted in two phases. In the first phase, the specimens with intact anterior inferior tibiofibular ligaments were tested. Longitudinal axis of the amputee was vertical to ground surface. Suitable gauge marks (diamond mark for high accuracy) for specimens were applied to test specimens with pins due to the sliding surface of test specimens. One of the gauge marks was placed to

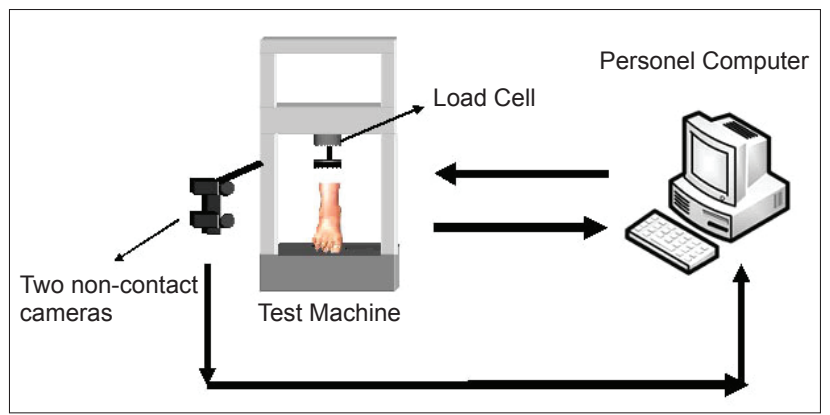

Figure 1. Schematic diagram of axial compression test includes axial compression test machine, amputee, double non-contact cameras, computer.

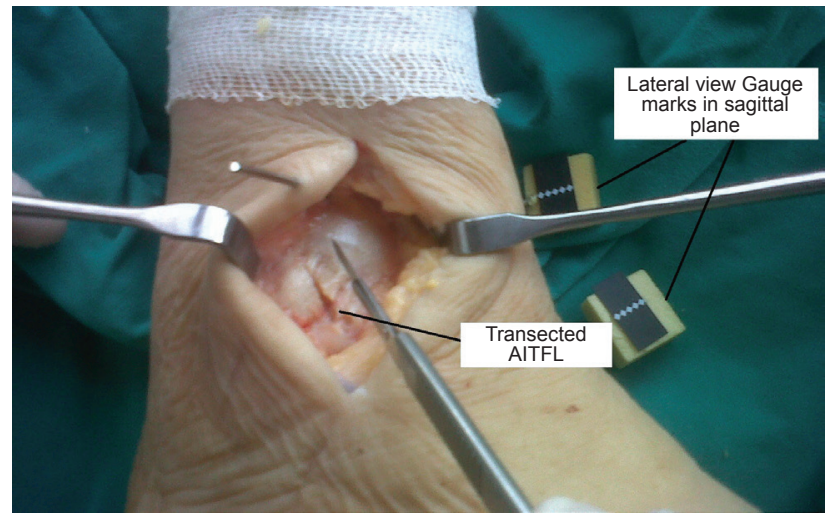

Figure 2. Transected Anterior Inferior Tibiofibular Ligament (AIT$\mathrm{FL}$ ) of a specimen and lateral view of upper and lower gauge marks in saggital plane.

distal tibia anteriorly I cm proximal from ankle joint level and the other one was attached to the neck of talus bone parallel with the proximal gauge mark in the same sagittal plane that was perpendicular with cameras. Axial compression load of maximum 800 Newtons was applied to each amputee material with a loading speed of $5 \mathrm{~mm} / \mathrm{min}$. Operating temperature was room temperature of $25^{\circ} \mathrm{C}$.

Non-contact measurements were carried out by two noncontact cameras that grabbed image of the gauge marks attached to the test specimens. Personal computer processed grey-scale image and measured the displacement of the gauge marks of each camera image from the initial processing result. The gauge length was measured as the distance between centers of the upper and lower gauge marks (Fig. 2). The gauge length on the CCD screen was converted into the actual distance to calculate the displacement of the test specimen. Converting ratio was calculated during calibration before measurement.

The second phase involved the division of the anterior inferior tibiofibular ligaments. The entire anterior inferior tibiofibular ligament was sectioned in its mid-substance (Fig. 2),

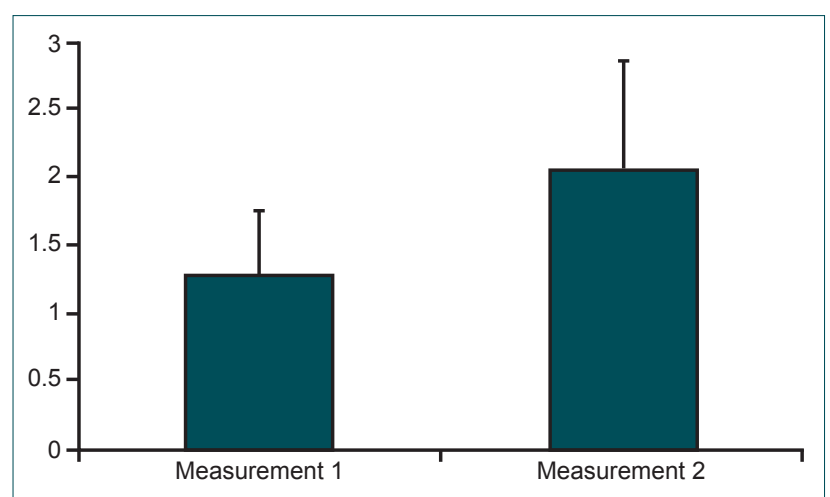

Figure 3. Mean displacement values of measurements of biomechanical test. Measurement 1 was mean displacement value of specimens in intact situation. Measurement 2 was mean displacement value of specimens after sectioning of ATIF ligament. 
Table I. Displacement values of biomechanical measurements of the specimens.

\begin{tabular}{llc}
\hline Patient & \multicolumn{2}{c}{ Displacement Values (mm) } \\
\cline { 2 - 3 } & Intact & AITFL sectioned \\
\hline No. I & 4.45 & 6.91 \\
No. 2 & 0.85 & 2.09 \\
No. 3 & 0.55 & 0.60 \\
No. 4 & 0.50 & 0.16 \\
No. 5 & 1.72 & 3.76 \\
No. 6 & 0.47 & 0.71 \\
No. 7 & 0.71 & 1.08 \\
No. 8 & 1.00 & 1.21 \\
\hline
\end{tabular}

AITFL: Anterior inferior tibiofibularis ligament

and measurements were made with an external load of 800 Newtons. The same procedure of biomechanical axial compression test was carried out as in the first phase.

For both phases, the results of displacement values were recorded on personnel computer connected with test machine and two non-contact cameras. The software produced the results of displacement and force on charts and the results were displayed on personnel computer screen. After the tests were performed, medial ligaments of the specimens were checked if they were intact ligaments by direct visualization after dissection. Clinically displacements of $2 \mathrm{~mm}$ and above are known as instability of ankle. The anterior displacement of fibula was reported to be an average of $1.2 \mathrm{~mm}$, with a sectioned AITFL. ${ }^{[2,6,14]}$

\section{Statistical Analysis}

Descriptive statistics and confidence limits were calculated with SPSS software (SPSS 15.0). Paired data analysis correlated with the biomechanical evaluation was performed to compare the displacement values of the specimens with AITFL intact and specimens with AITFL sectioned. Comparisons of the results of the two phases were made by Wilcoxon signed rank test. Differences were considered statistically significant when $\mathrm{P}$ was less than or equal to $0.05(0.05 \geq \mathrm{P})$.

\section{RESULTS}

In both phases of this study, 800 Newtons axial loads were applied to intact AITFL of ankle at neutral position. According to the results of this biomechanical study, talus anterior displacement values were shown in Table I. Displacement results of the gauge marks under compression during the anterior spin of the foot and the posterior spin of the distal tibia were measured by laterally placed noncontact CCD video extensometer cameras positioned in a perpendicular fashion to the ankle and gauge marks. Mean AITFL-Intact ankle anteroposterior gauge displacement was $1.28 \pm 0.47 \mathrm{~mm}$ (Fig. 3). Mean AITFL-Dissected ankle anteroposterior gauge displacement was $2.06 \pm 0.7 \mathrm{~mm}$ (Fig. 3). In general, all displacement results of the specimens were similar but the displacement result of specimen number five was obviously different. There was a statistically significant difference between the anteroposterior displacement values for AITFL-Intact and AITFL-Dissected specimens ( $p \leq 0.05)$. Vertical stiffness values (MPa) for amputees with intact AITFL and dissected AITFL were presented in Table 2. There was no difference in stiffness between AITFL-Intact and AITFL-Dissected specimens $(p \leq 0.05)$.

\section{DISCUSSION}

Ankle injury, which is currently a very important problem affecting many people, is the most common sports injury. After ankle sprain, some patients continue to experience the following complaints: intermittent ankle pain, swelling, sense of instability, and recurring pain..$^{[2,4,13,15,16]}$ It is calculated that the likelihood of a new sprain following lateral injury is increased twice or three times. ${ }^{[13,15]}$ Ankle stability is dependent upon load level direction of forces applied and ligament integrity. ${ }^{[14]}$ Most commonly, the AITFL is ruptured. This anterior syndesmotic diastasis is an open book injury resulting from external rotation of fibula. In the external rotation of the ankle, a greater strain occurs on the AITFL. In this injury, application of plaster provides recovery; however, if a proper treatment is not given in the early stage, chronic instability and pain may occur in the late period.

In our study, the lateral displacement of talus was measured under 800 Newtons axial loads with an intact AITFL after its

Table 2. Vertical stiffness values $\left(k_{\text {vert }}\right)$ for amputees with intact ATIFL and amputees with dissected ATIFL (N/mm)

\begin{tabular}{|c|c|c|c|c|c|c|c|c|}
\hline & No I. & No 2 . & No 3. & No 4. & No 5 . & No 6. & No 7. & No 8 . \\
\hline $\begin{array}{l}\text { Stiffness values }\left(k_{\text {vert }}\right) \text { of amputees } \\
\text { with intact ATIFL }(n=8)\end{array}$ & 179.78 & 941.18 & 1454.55 & 1600 & 465.12 & 1702.13 & 1126.76 & 800 \\
\hline $\begin{array}{l}\text { Stiffness values }\left(k_{\text {vert }}\right) \text { of amputees } \\
\text { with dissected ATIFL }(n=8)\end{array}$ & 115.77 & 382.78 & 1333.33 & 5000 & 212.77 & 1126.76 & 740.74 & 661.16 \\
\hline
\end{tabular}

Formula for calculating stiffness : VERTICAL STIFFNESS $\left(k_{\text {vert }}\right) \rightarrow k_{\text {vert }}=$ Fmax $/ \Delta y($ McMahon and Cheng, 1990) where Fmax $=$ maximum vertical force; $\Delta y=$ maximum vertical displacement measured by test machine (AG-IS 10 kN, Shimadzu Corporation, Kyoto, Japan) 
sectioning in the human ankle at neutral position. The displacement values of AITFL intact and AITFL sectioned were compared. It was found that measured anterior displacement values at AITFL sectioned were about twofold more than from AITFL intact values. The displacement values found in our study for the anterior displacement of talus were close to the measured values in the literature. Beumer et al. ${ }^{[14]}$ have measured anterior fibular displacement under axial load after the sectioning of AITFL, and their measurements have been taken with the ankle at neutral position. They have found I.I mm - $2.6 \mathrm{~mm}$, which are similar values to our study. In AIFTL isolate rupture, the lateral displacement of the fibula is reported in the average $1.2 \mathrm{~mm}$ since other ligaments are intact and the fibula cannothave excessive displacement. ${ }^{[6,7,14]}$

In this study, the anterior displacement and anterior instability of the talus was investigated under axial load at neutral position. Beumer et al. ${ }^{[14]}$ have reported that it is of interest that in the neutral situation, displacements were found after sectioning the ligaments because the level of the distal tibiofibular syndesmosis in the horizontal plan may be considered to be a ring. The ring is composed of anterior tibiofibular ligament, fibula, posterior tibiofibular ligament and tibia. ${ }^{[14]}$ The talus is located in the center of the ring. When the ring is disrupted at one level, for example AITFL, the rest tension of the ring cannot be maintained, and there will be a relaxation at the posterior tibiofibular ligament and posterior capsule. In this situation, the fibula will be displaced. ${ }^{[14]}$ In our study, the anterior displacement of the talus was measured mean I.4 $\mathrm{mm}$. Since the values found were very small, AITFL injuries were difficult to detect in acute stage. This situation constitutes ankle stability and some patients may experience ankle pain while walking and doing some activity. ${ }^{[7,17]}$ Post traumatic anterolateral instability due to an injured and torn AITFL results in anterolateral extorsion of the talar dome, and it may cause impingement syndromes of the ankle. Unstable ankles may lead to the formation of fibrosis granulation tissue. ${ }^{[7]}$ In the current study, when the AITFL was sectioned, the anterior displacement of the talus was measured $0.45 \mathrm{~mm}$ to $2.45 \mathrm{~mm}$. It is similar to previous studies where the anterior displacement of fibula was reported to be an average of 1.2 $\mathrm{mm}$, with a sectioned AITFL. ${ }^{[2,6,14]}$ Watanabe et al. ${ }^{[18]}$ have shown that under external load of the ankle, peak strains in the AITFL occur prior to peak strain in the AITFL. Deltoid ligament rupture occurs after AITFL rupture.

Posterior displacement of the distal tibia in this biomechanical axial compression setup should be considered as the anterior instability of the ankle joint during axial weight-bearing phase of human gait stance phase.

In order to understand antero-posterior instability due to AITFL injuries during all phases of human gait, advanced new dynamic studies including not only human gait at stance phase as measured in this study but also all phases of human gait, were required. This study was a pilot study for the require- ment of data on AITFL biomechanics, and new studies are required for understanding AITFL biomechanics.

Our limitation in this study was the median age of the patients to whom the specimens belonged to, which was 66 years of age (range 54-82). Therefore, biomechanical study didn't evaluate the young population. However, the situation of old population didn't affect the results as this was a comparison of two groups in biomechanical study. Instead of static position, dynamic or different foot positions may give more information about the biomechanics of AITF ligaments.

\section{Conclusion}

In living humans, it may be crucial in understanding the ankle function and injury mechanisms. ${ }^{[17,19]}$ It may be explained why AITFL is injured more than the other ligaments in the ankle under external rotation load. Our findings in this study showed that talus instability and talus displacement may occur in AITFL injuries of the ankle. In the emergency department, diagnosis and treatment of AITFL injury due to ankle distortion is important. In AITFL injuries, ankle biomechanics is affected and ankle instability occurs.

Displacement values for AITFL-Dissected specimens may be evidence for tendency to anteroposterior displacement and biomechanical insufficiency under axial compression during foot in neutral position, giving the impression that AITFL deficient-ruptured patients are being exposed to more instable and degenerative processes during axial weight-bearing of ankle at stance phase of gait. Since distal tibial joint surface has an anteroposterior inclination at horizontal axis, AITFL plays an important stabilizer role during axial loading of ankle joint. Randomized, controlled, dynamically measured further trials are necessary to identify more real-time biomechanical behavior of AITFL contributing to ankle stability during all phases of human gait and axial ankle loading.

This study will provide basic knowledge for future studies of ankle joint biomechanics, which will shed light on clinical studies relevant to ankle.

Conflict of interest: The authors confirm that there is no conflict of interest regarding the publication of this manuscript. We had no financial and personal relationships with other people or organizations that could inappropriately influence (bias) our work.

\section{REFERENCES}

1. Chan KW, Ding BC, Mroczek KJ. Acute and chronic lateral ankle instability in the athlete. Bull NYU Hosp Jt Dis 2011;69:17-26.

2. Title CI, Katchis SD. Traumatic foot and ankle injuries in the athlete. Orthop Clin North Am 2002;33:587-98. CrossRef

3. Norkus SA, Floyd RT. The anatomy and mechanisms of syndesmotic ankle sprains. J Athl Train 2001;36:68-73.

4. Clanton TO, Paul P. Syndesmosis injuries in athletes. Foot Ankle Clin 
2002;7:529-49. CrossRef

5. Beumer A, van Hemert WL, Swierstra BA, Jasper LE, Belkoff SM. A biomechanical evaluation of the tibiofibular and tibiotalar ligaments of the ankle. Foot Ankle Int 2003;24:426-9.

6. Xenos JS, Hopkinson WJ, Mulligan ME, Olson EJ, Popovic NA. The tibiofibular syndesmosis. Evaluation of the ligamentous structures, methods of fixation, and radiographic assessment. J Bone Joint Surg Am 1995;77:847-56.

7. van den Bekerom MP, Raven EE. The distal fascicle of the anterior inferior tibiofibular ligament as a cause of tibiotalar impingement syndrome: a current concepts review. Knee Surg Sports Traumatol Arthrosc 2007; 15:465-71. CrossRef

8. Hintermann B. Biomechanics of the ligaments of the unstable ankle joint. [Article in German] Sportverletz Sportschaden 1996;10:48-54. [Abstract]

9. Taylor DC, Englehardt DL, Bassett FH 3rd. Syndesmosis sprains of the ankle. The influence of heterotopic ossification. Am J Sports Med 1992;20:146-50. CrossRef

10. Taylor DC, Bassett FH. Syndesmosis ankle sprains: diagnosing the injury and aiding recovery. Physician Sportsmed 1993;21:39-46.

11. Boytim MJ, Fischer DA, Neumann L. Syndesmotic ankle sprains. Am J Sports Med 1991;19:294-8. CrossRef

12. Wang Q, Whittle M, Cunningham J, Kenwright J. Fibula and its ligaments in load transmission and ankle joint stability. Clin Orthop Relat Res 1996;330:261-70. CrossRef
13. Kumar V, Triantafyllopoulos I, Panagopoulos A, Fitzgerald S, van Niekerk L. Deficiencies of MRI in the diagnosis of chronic symptomatic lateral ankle ligament injuries. Foot and Ankle Surgery 2007;13:171-6.

14. Beumer A, Valstar ER, Garling EH, Niesing R, Ginai AZ, Ranstam J, et al. Effects of ligament sectioning on the kinematics of the distal tibiofibular syndesmosis: a radiostereometric study of 10 cadaveric specimens based on presumed trauma mechanisms with suggestions for treatment. Acta Orthop 2006;77:531-40. CrossRef

15. Urgüden M, Kızılay F, Sekban H, Samancı N, Ozkaynak S, Ozdemir H. Evaluation of the lateral instability of the ankle by inversion simulation device and assessment of the rehabilitation program. Acta Orthop Traumatol Turc 2010;44:365-77. CrossRef

16. Bonnel F, Toullec E, Mabit C, Tourné Y; Sofcot. Chronic ankle instability: biomechanics and pathomechanics of ligaments injury and associated lesions. Orthop Traumatol Surg Res 2010;96:424-32. CrossRef

17. Wei F, Braman JE, Weaver BT, Haut RC. Determination of dynamic ankle ligament strains from a computational model driven by motion analysis based kinematic data. J Biomech 2011;44:2636-41. CrossRef

18. Watanabe K, Kitaoka HB, Berglund LJ, Zhao KD, Kaufman KR, An $\mathrm{KN}$. The role of ankle ligaments and articular geometry in stabilizing the ankle. Clin Biomech (Bristol, Avon) 2012;27:189-95. CrossRef

19. Stufkens SA, van Bergen CJ, Blankevoort L, van Dijk CN, Hintermann B, Knupp M. The role of the fibula in varus and valgus deformity of the tibia: a biomechanical study. J Bone Joint Surg Br 2011;93:1232-9. CrossRef

\title{
DENEYSEL ÇALIŞMA - ÖZET
}

\section{Tibiofibularis anterior ligamanının ayak bileği eklemi biyomekaniğine etkisi}

\author{
Dr. Ahmet Karakaşı, ${ }^{1}$ Dr. Mehmet Erduran, ${ }^{1}$ Dr. Lütfü Baktıroğlu, ${ }^{2}$ Dr. Aydın Büdeyri, ${ }^{3}$ \\ Dr. Didem Venüs Yıldız, ${ }^{4}$ Dr. Hasan Havıtçıoğlu ${ }^{1}$
}

\author{
1'Dokuz Eylül Üniversitesi Tıp Fakültesi, Ortopedi ve Travmatoloji Anabilim Dalı, İzmir; \\ ${ }^{2}$ Çanakkale Onsekiz Mart Üniversitesi Tıp Fakültesi, Ortopedi ve Travmatoloji Anabilim Dalı, Çanakkale; \\ ${ }^{3}$ Özel Sani Konukoglu Hastanesi, Ortopedi ve Travmatoloji Kliniği; Gaziantep; \\ ${ }^{4}$ Dokuz Eylül Üniversitesi Sağlık Bilimleri Enstitüsü, Biyomekanik Anabilim Dalı, İzmir
}

AMAÇ: Bu çalışmanın amacı duruş fazında aksiyel yüklenme altında insan ayak bileğinin anterior inferior tibiofibularis ligamanının (AITFL) biyomekanik davranışını değerlendirmektir. Duruş fazında ayak bileği stabilitesine AITFL'nin etkisini araştırmak için in vitro ardaşık deneysel bir düzenek simüle edildi.

GEREÇ VE YÖNTEM: Aksiyel kompresyon gerçekleşirken nötral posizyonda ayağın anterior yerdeğişimi ve distal tibianın posterior yerdeğişimi ölçümü iki non-kontakt vidyo ekstansiyometre ile gerçekleştirildi. Sekiz taze donmuş ve anatomik olarak sağlam insan kadavra ayak bileği örnekleri test edildi. Aksiyel kompresyon test makinesi, duruş fazında aksiyel ayak bileği yüklenmesini simüle etmek için 0’dan 800 Newton'a kadar yüklenme ile ve $5 \mathrm{~mm} / \mathrm{dk}$ yükleme hızında kullanıldı.

BULGULAR: AITFL-sağlam ve AITFL-kesilmiş örneklerde anteroposterior yerdeğiştirme arasında istatistiksel olarak anlamlı fark gözlendi. Ortalama AITFL-sağlam ayak bileği anteroposterior yerdeğişimi I.28 $0.47 \mathrm{~mm}$ idi. Ortalama AITFL-kesik ayakbileği anteroposterior yerdeğişimi $2.06 \pm 0.7$ mm idi.

TARTIŞMA: Sonuç olarak, ayak bileği nötral pozisyondayke AITFL'nin biyomekanik özellikleri hakkında bazı nümerik ve kantitatif bilgi vermektedir. Acil serviste ayakbileği distorsiyon sonrası AITFL yaralanması teşhisi ve tedavisi önemlidir. Ayak bileği biyomekaniği AITFL yaralanmaları sonrası etkilenmekte ve instabilite gelişmektedir.

Anahtar sözcükler: Aksiyel kompresyon testi; anterior inferior tibiofibular ligamanı; ayak bileği biyomekaniği; yer değiştirme.

Ulus Travma Acil Cerrahi Derg 20I5;2I(2):90-95 doi: 10.5505/tjtes.20I5.27I63 